\title{
Intellectual Capital, Knowledge Sharing, and Innovation Performance: Evidence from the Chinese Construction Industry
}

\author{
Yongfu $\mathrm{Li}^{1}$, Yu Song ${ }^{1, *}$, Jinxin Wang ${ }^{2}$ and Chengwei $\mathrm{Li}^{1}$ \\ 1 School of Management Engineering, Shandong Jianzhu University, Jinan 250101, China; \\ lyf58566@126.com (Y.L.); $115966697329 @ 126 . c o m$ (C.L.) \\ 2 Engineering Audit Section of Audit Office, Shandong Normal University, Jinan 250358, China; \\ 15662751589@163.com \\ * Correspondence: sy15966697379@126.com; Tel.: +86-159-666-973-79
}

Received: 12 April 2019; Accepted: 6 May 2019; Published: 13 May 2019

\begin{abstract}
Knowledge economy era is an era driven by innovation, mainly based on the input of intangible assets which plays decisive roles in the long-term development of enterprises. The product value of enterprises is largely determined by their intellectual capital. Therefore, as pillars of China's economy, construction enterprises must strengthen their investments in intellectual capital, and to achieve competitiveness in the market, enterprises must share knowledge with the other members of their networks. This study explores the relationship among the intellectual capital, knowledge sharing, and innovation performance of construction enterprises and the mediating effect of knowledge sharing on the relationship between intellectual capital and innovation performance by using data collected from a questionnaire survey. These data are analyzed along with the aforementioned relationships by using SPSS and a structural equation model. The findings indicate that intellectual capital not only has a direct positive influence on the innovation performance of construction enterprises but also positively affects their innovation performance through knowledge sharing. This paper concludes by presenting its limitations and the implications of its findings.
\end{abstract}

Keywords: intellectual capital; knowledge sharing; innovation performance; construction industry

\section{Introduction}

In the knowledge economy era, industries have gradually transformed from labor intensive to knowledge intensive [1]. To this end, enterprises have increasingly depended on intangible assets, including knowledge, corporate culture, human creativity, and innovation, to create value [2]. Innovation plays an indispensable role in gaining and sustaining the competitive advantage of enterprises, including construction enterprises [3-5]. By engaging in product and service innovation, enterprises can improve their performance and maintain a competitive advantage in the market $[6,7]$. The operating environment of enterprises is among those factors that contribute to their innovation. For instance, those enterprises operating in a dynamic environment face huge challenges from constantly changing internal and external factors, and an enterprise that fails to respond to these changes may be eliminated from the market. Innovation can also promote the sustainable development of countries [8], that is, the sustainable development of an economy hinges on its innovation. Accordingly, many countries have begun to acknowledge the importance of innovation as a driver of economic growth [3]. As pillars of China's economy, construction enterprises increase their competitiveness in the market by concentrating on their innovation efforts [9] and gain a competitive advantage over their competitors by properly orientating their innovation processes [10]. 
In the 21st century, project-based industries, particularly the construction industry, are facing much pressure to compete in new ways; the enterprises in these industries must possess the relevant knowledge and intellectual capital to realize innovation, and intellectual capital plays an important role in achieving such goal [11]. Measuring intellectual capital at the national level can help analyze and compare the competencies and capacities of an economy as well as contribute to the adoption and adjustment of policies and practices for promoting economic development [12]. As a core element of invisible assets that are viewed as core competencies in the market, intellectual capital is crucial for enterprises to achieve an excellent performance and receive long-term profits. In other words, intellectual capital is essential in achieving innovation [1], and the innovation of an enterprise is closely related to its intellectual capital $[13,14]$. Egbu [15] argues that construction enterprises should adopt various and targeted measures (such as education and training of construction personnel and promoting an innovation-supporting culture) that can improve intellectual capital to realize innovation. Other researchers describe the present society as a knowledge-based society in which the storage and application of knowledge serve as bases for the capital accumulation of enterprises. Many industries in such society, including the construction industry, depend on knowledge management rather than traditional production factors (e.g., equipment and labor) to achieve and sustain their competitive advantage in the market. Following these arguments, the importance of knowledge management and intellectual capital needs to be highlighted. Previous studies show that intellectual capital and knowledge sharing can stimulate both innovation and innovation performance [1,16-19], but not all enterprises, specifically from the construction industry, have truly realized the potential benefits of these factors.

Previous studies suggest that innovative enterprises generally outperform those that lack innovation [4]. However, only few construction enterprises are engaging in innovation activities. The construction industry serves as the pillar industry of China's economy, and the development of construction enterprises is directly related to China's economic development. Innovation plays a vital role in the construction industry. Specifically, the realization of innovation projects is closely related to improvements in the innovation ability and performance of construction enterprises and can significantly influence their competitiveness. China's construction industry is known for its low level of innovation and its dependence on labor to complete its projects. However, to adapt to an era of knowledge economy, this industry must start adopting advanced technologies [20,21]. Accordingly, project innovation, as one driver of the growth of the construction industry, has received the attention of many researchers [22,23].

While many studies have examined the impact of intellectual capital on innovation performance, only few have considered the factor of knowledge sharing and analyzed the relationship among intellectual capital, knowledge sharing, and innovation performance of the construction industry [24]. In addition, these studies have mostly focused on enterprises from different industries without any specificity, and the mediating effect of knowledge sharing on the relationship between intellectual capital and innovation performance in the construction industry remains largely unexplored. These gaps in the literature highlight the importance of examining the relationships among the intellectual capital, knowledge sharing, and innovation performance of construction enterprises, and this paper aims to address such gaps.

Given the lack of information about the intellectual capital, knowledge sharing, and innovation performance of construction enterprises, this paper examines the role of intellectual capital in innovation performance of construction enterprises and investigates the role of knowledge sharing as a possible intervening mechanism that mediates the relationship between intellectual capital and innovation performance. In other words, this exploratory study attempts to identify the relationship among the intellectual capital, knowledge sharing, and innovation performance of construction enterprises.

This study chooses the construction industry as its context given that the construction sector is not only an important contributor to human settlements but also serves as a key driver of economic 
growth. In other words, this industry plays a critical role in the economic and societal development of a country [25].

This paper is organized as follows. First, the research background about intellectual capital, knowledge sharing, and innovation performance in construction industry is introduced. Second, the relationships among intellectual capital, innovation performance, and knowledge sharing is examined by reviewing the literature, and corresponding research hypotheses are proposed. Third, the research design, including the sample, data collection procedures, and related measurements are presented. Fourth, the results of the data analysis are discussed. Fifth, the paper concludes by presenting its limitations, the implications of its findings, and some directions for future work.

\section{Research Background}

\subsection{Intellectual Capital}

The concept of intellectual capital has emerged in the early 1980s in response to the need for business practitioners to understand the basis of organizational performance. Since then, this concept has evolved into a popular academic approach that is widely adopted by academics in the 1990s [26,27]. Research on intellectual capital can be divided into four stages. The first stage (early 1980s to mid-1990s) has mainly focused on further understanding intellectual capital and its importance for organizations to gain and sustain their competitive advantage in the market. The second stage (late 1990s to early 2000s) has examined the value of intellectual capital in helping enterprises achieve a positive financial performance [27], focused on its measurement, management, and reporting, and proposed different classifications of such concept [28]. The third stage (mid-2000s to early 2010s) has examined how managers can use intellectual capital to manage and run their businesses $[29,30]$ and strengthen their organizations. The fourth stage (mid 2010s to present) complements the previous stage by focusing on building strong social, economic, and environmental ecosystems where organizations can improve in a healthy and vigorous way [31].

Several definitions of intellectual capital have been proposed in the literature. For instance, Nahapiet and Ghoshal [32] define intellectual capital as a type of knowledge and the cognitive ability of a social collective (e.g., intellectual communities and organizations) to gain a competitive advantage. Youndt, et al. [33] conceptualize intellectual capital as the sum of all knowledge that can be leveraged by organizations in their search for a competitive advantage. Many other scholars define intellectual capital as a collection of intangible assets, including enterprise culture, innovation, human creativity, and knowledge [34]. In sum, intellectual capital refers to valuable knowledge-related resources (e.g., knowledge, human creativity, experience, organizational technology, customer relationships, and professional skills) that organizations possess and use to create value and achieve a competitive advantage.

Previous studies have also proposed many frameworks to explore intellectual capital and to facilitate its operation at the enterprise level. Intellectual capital has various components, with human capital, structural capital, and relational capital being the most prominent components [14,34-38] that have been widely examined in the literature [39]. Human capital refers to the members of an organization and their knowledge, skills, motivation, attitudes, and education [32,40,41]. This type of capital is also regarded as the most significant component of intellectual capital given that an enterprise cannot achieve anything (including innovation) without human capital [42]. Structural capital encompasses "all non-human storehouses" of knowledge within organizations [43] that are accumulated and distributed through their structure, organizational culture, and information and management systems $[40,44]$. These resources are always owned by an enterprise and cannot be taken away by its employees upon their departure [45]. Relational capital refers to the value of an organization's relationship with the other members of its business community [45], including the stakeholders of a project, cooperation partners, and customers [46]. Some researchers, such as Edvinsson and Malone [14], argue that these three components of intellectual capital reciprocally circulate and 
influence one another. Meanwhile, Stewart and Ruckdeschel [38] add that these components are complementary and that intellectual capital is most effective when these three components support one another.

Intellectual capital is widely regarded as the foundation of a country's or regions' future rapid economic growth and wealth accumulation, and its components play crucial roles in achieving sustainable development. Highlighting the importance of intellectual capital not only enhances competitive advantage but can also benefit sustainability and economic growth [47]. In the globalization era, intellectual capital is increasingly regarded as an important factor for improving the non-financial [48] and innovative performance of enterprises [1,49].

\subsection{Knowledge Management in the Construction Industry}

An increasing number of enterprises in the knowledge economy era have begun to consider knowledge as an important asset and have implemented their own knowledge management strategies accordingly [16]. Knowledge management plays a crucial role in improving the performance of enterprises and helping them achieve a competitive edge [50,51]. Through knowledge management, an enterprise can easily gain the expertise or know-how that is formally recorded in someone's mind [46]. Many studies have also regarded knowledge management as a framework for designing strategies that can help enterprises learn and create value [52].

Faced with various challenges, construction enterprises need to adopt some strategies to maintain their competitiveness in the market. Faraj, et al. [53] argue that these enterprises must possess high-quality knowledge about their products, services, and technologies to successfully carry out their projects in a competitive market. Kamara, et al. [54] suggest that when facing challenges, these enterprises must recognize the importance of their management projects and organizational knowledge, both of which are essential for them to remain competitive and respond to the needs of their customers.

Knowledge management refers to the action of enterprises to maximize their use of available knowledge resources, including explicit and implicit knowledge [55]. The construction industry is a knowledge-intensive industry known for its unique working environment and virtual organization operation mode [56]. Some knowledge management initiatives in this industry have successfully raised the awareness of construction enterprises regarding the potential of knowledge management to improve their innovation performance. However, this industry remains slow in taking advantage of knowledge management technologies, such as document management systems to evaluate the progress of construction projects [57] and camera-based personnel tracking systems [58] to monitor and manage workers at construction sites.

The knowledge management process involves knowledge acquisition, knowledge creation, knowledge sharing, and knowledge utilization [59], with knowledge sharing being the most important component. Knowledge sharing is essentially an interactive process where the knowledge owner compiles knowledge in the form of information and transmits such information to the receiver through several media [60]. For construction enterprises, the information exchange between organizations is key to knowledge sharing. Lin [61] argues that knowledge sharing can create opportunities for solving problems and improving problem-solving efficiency, both of which create initial value for the successful implementation of an innovation project. Meanwhile, Zhang, et al. [62] contend that knowledge sharing plays a vital role in the creation of knowledge and value.

Knowledge management is particularly important in the construction industry give its role in the continuous improvement of enterprises, dissemination of best practices to key employees, the retention and storage of the tacit knowledge of key employees, the need for a quick customer response, and the need for knowledge sharing [63].

Knowledge management is also vital for achieving innovation and sustainability. Organizations adopt this organic approach to achieve a sustainable development [64]. Without an effective knowledge management to promote knowledge integration, organizations may be unable to fully utilize their knowledge as a source of innovation and may not be able to smoothly realize innovation $[65,66]$. 


\subsection{Innovation in the Construction Industry}

Innovation refers to the process of discovering or creating new ideas [67]. This concept cannot be defined from a single or simple dimensionality perspective. Innovation may be viewed as a novel product, but in other contexts, innovation may refer to a new production process, the use of cheap materials to finish a project without changing the nature of the product, or improvements in the tools or methods for achieving innovation [68]. Manual [69] defines innovation as the implementation of a new product, process, marketing method, or organizational method in a specific context. These various definitions have given rise to a diverse range of innovation types, including product or process innovation, marketing or organizational innovation, incremental or radical innovation, technological or managerial innovation, and market pulling or technology pushing innovation.

The success of an enterprise depends on its innovations and adoption of new technologies, which have critical influences on the dynamics of their external environment and competition. The construction industry is a labor-intensive industry characterized by its poor innovation compared with other industries, especially in developing countries. However, many practitioners and academics have begun to highlight the importance of project innovation in this construction industry [10,70-72]. Given the increasing emphasis on its importance, this paper focuses of the concept of innovation.

\subsection{Interrelationship among Intellectual Capital, Knowledge Management, and Innovation}

Based on knowledge-based view, knowledge is considered both a resource and a capability. For enterprises, effectively managing and maximizing their use of knowledge is critical to their achievement of a competitive advantage [73]. To implement knowledge management in construction enterprises, an intellectual capital portfolio must be cultivated to achieve a synergy of competent employees, knowledge-oriented culture, organizational infrastructure, and favorable relationship with stakeholders [74]. Knowledge management also creates platforms and processes for the creation, sharing, and utilization of tacit knowledge in organizations, thereby benefitting the innovation process [75].

Intellectual capital is an effective and important means for enterprises to perform knowledge management. Only when externally shared, integrated, and utilized, the acquired knowledge can be successfully transformed into new products, technologies, and services to meet the needs of customers and to improve the innovation performance of enterprises.

\section{Hypotheses}

\subsection{Intellectual Capital and Innovation Performance}

Many studies have identified intellectual capital as one of the most important elements for achieving innovation performance. In the knowledge economy era dominated by intellectual capital, traditional financial statements only report intangible assets (e.g., licenses, patents, and trademark). Intellectual capital is an important asset for those enterprises that want to achieve efficient operations and maintain their competitive advantage in the market [76]. Chen, et al. [77] argue that an enterprise with a greater amount of intellectual capital has a stronger innovation ability and better innovation performance compared with those enterprises with low intellectual capital. Zerenler, et al. [1] find that the three types of intellectual capital are positively related with innovation performance.

H1: Intellectual capital positively affects the innovation performance of the construction industry.

\subsubsection{Human Capital and Innovation Performance}

How to achieve innovation among enterprises is a human problem above all [42]. The knowledge and skills that enterprises need to create innovation are being used by their very own employees. In the value creation process, innovation activities often rely heavily on the knowledge, skills, and experiences of employees [78]. At the organizational level, human capital refers to the capabilities, 
knowledge, skills, and experiences of an enterprises' employees and managers that can be used to promote innovation activities to a certain extent [79]. Human capital is an important intangible asset possessed by enterprises, especially in their pursuit of innovation [80]. Enterprise innovation essentially relies on the utilization of existing knowledge to create new knowledge and involves the continuous accumulation of enterprise knowledge, technologies, and other resources. Therefore, as the carrier of the knowledge, employees play important roles in achieving enterprise innovation [81]. Creative and knowledge-based employees are highly likely to generate new ideas and improve the innovation performance of enterprises.

H1a: Human capital positively affects the innovation performance of the construction industry.

\subsubsection{Structural Capital and Innovation Performance}

Structural capital refers to the knowledge repository of all non-human resources in an organization. Enterprises mainly accumulate structural capital from their organizational structures, practices, information systems, and manuals. The knowledge and experience generated in the process of organizational practice will be institutionalized and systematized and will not be taken away by employees upon their departure from an enterprise. In a market economy, enterprises are the main participants in the development and commercialization of new products and processes, and organizational culture can drive an enterprise to formulate an innovation strategy that can help achieve its innovation goals and improve its innovation performance [82]. The institutionalization of knowledge and systematic experience can promote enterprise innovation because enterprises mainly generate new products or services by applying their existing knowledge and experiences, combining their previous knowledge, and accumulating their experiences to solve existing problems [42]. By establishing an organizational structure, construction enterprises can save the documents and various records that they generate during a construction project in an information system, which can help them constantly generate and test new ideas [83]. The culture, organizational structure, construction process, and rules and regulations of construction enterprises offer them a solid foundation to achieve smooth operations and achieve innovation in their project implementation.

H1b: Structural capital positively affects the innovation performance of the construction industry.

\subsubsection{Relational Capital and Innovation Performance}

Relational capital is an interpersonal relationship based on trust, commitment, and respect to customers, suppliers, governments, or other stakeholders. Not all the knowledge required for enterprise innovation can be found within an enterprise. Some enterprises may achieve innovation and improve their innovation performance by using the solutions possessed by other organizations as reference or by combining their knowledge with external accessible knowledge. Several studies have examined the relational capital of organizations and find that interorganizational relationships create opportunities for enterprises to acquire external knowledge and combine such knowledge with their existing knowledge resources [84]. In addition, by fulfilling their promises to one another, those enterprises in a network of external relations demonstrate a cooperative innovation behavior, which can help them gain valuable knowledge and resources from the outside to improve their innovation performance [85].

Ghorbani [86] reveals a significant relationship between relational capital and organizational innovation. Sulistyo [87] argues that the innovation ability of enterprises plays a very significant role in improving their performance and competitive advantage and add that the innovation ability of these enterprises can be improved by relational capital. Furthermore, having high innovation capabilities can improve the performance of enterprises [88].

H1c: Relational capital positively affects the innovation performance of the construction industry. 


\subsection{Intellectual Capital and Knowledge Sharing}

According to Heisig [89], the critical success factors involved in knowledge management include human-oriented factors (culture, people, and leadership), organization-oriented factors (processes and structures) and management-processes-oriented factors (strategy, goals, and measurement). Obeidat, et al. [90] add that intellectual capital can facilitate knowledge sharing.

H2: Intellectual capital positively affects knowledge sharing in the construction industry.

\subsubsection{Human Capital and Knowledge Sharing}

Human capital is regarded as the most important intangible asset of an organization, the cornerstone of all types of knowledge, and the main source of intelligence, knowledge, innovation, and invention for an enterprise [90], therefore, human capital is essential for knowledge sharing. The attitude and willingness of knowledge workers determine whether their knowledge can be shared with the other employees [78]. The importance of management support to the success of a team lies in the provision of the necessary policy support and the allocation of resources as needed, both of which reflect the capability of managers [91]. According to Egbu [15], construction leaders must involve knowledge workers in dynamic knowledge management to promote knowledge sharing. Employee formal education and training are among the most important factors that benefit the promotion of knowledge sharing.

H2a: Human capital positively affects knowledge sharing in the construction industry.

\subsubsection{Structural Capital and Knowledge Sharing}

The positive factors of knowledge management, including technology, structure, and culture, can influence knowledge sharing [92,93]. Byrne argues that the organizational structure plays an important role in promoting knowledge sharing [94], whereas Egbu [15] contends that having a robust organizational infrastructure, flexible knowledge structure, knowledge-friendly culture, and positive motivational practices can promote knowledge sharing. Meanwhile, Zin and Egbu [95] suggest that organizations must promote an open culture to successfully implement knowledge sharing, and De Long and Fahey [96] reveal that the influence of culture on knowledge sharing can reach as high as $80 \%$. Furthermore, Abzari and Teimouri [97] highlight a positive correlation between organizational structure and knowledge sharing, and Ismail, et al. [98] identify enterprises culture as the most important factor for improving innovation performance.

H2b: Structural capital positively affects knowledge sharing in the construction industry.

\subsubsection{Relational Capital and Knowledge Sharing}

Knowledge sharing lies at the core of the knowledge management process, and relational capital can promote an interpersonal communication that can benefit the integration, sharing, and creation of knowledge [99]. Mu and Benedetto [100] argue that if an enterprise has a reciprocal relationship network, then the members of this network can easily meet one another's demands, thereby promoting cooperation, encouraging knowledge exchange and sharing, and improving the resource integration efficiency.

In many cases, alliance partners are important sources of new ideas and knowledge that can be used to enhance the value of an enterprise. High levels of interaction can strengthen the social ties among partners, strong relationships can improve the closeness of interactions, and close interactions can promote knowledge exchange and transfer as well as achieve knowledge sharing [101]. According to Krishnan, et al. [102], an interfirm relationship may be an important source of competitive advantage given that such relationship can create effective information-sharing routines. Meanwhile, Zin and 
Egbu [95] argue that the advent of alliances, joint ventures, and contracting in the construction industry has increased the need for further collaboration and knowledge sharing.

H2c: Relational capital positively affects knowledge sharing in the construction industry.

\subsection{Knowledge Sharing and Innovation Performance}

Given that the characteristics of enterprises are specific, socially complex, and path dependent, knowledge sharing is viewed as a valuable input for innovation. Accordingly, an increasing number of researchers have begun to explore the association between knowledge sharing and innovation [103,104]. From the perspective of economics and psychology, Homans [105] proposes social exchange theory, which posits that all human behavior is an act of exchange. This theory views knowledge sharing as a social exchange that increases the total amount of knowledge, produces innovations, and improves innovation performance. Lin [61] adds that knowledge sharing within enterprises can positively influence innovation capabilities and that organizational innovation capability can positively influence organizational innovation performance. Qammach [106] states that knowledge sharing can positively influence innovation performance and that organizations must attach great importance to knowledge sharing. Many researchers have also pointed out that an enterprise that facilitates the sharing of knowledge practices within a team or the entire organization tends to generate new ideas for introducing new business opportunities, thereby fostering innovation and improving innovation performance $[107,108]$.

H3: Knowledge sharing positively affects the innovation performance of the construction industry.

\subsection{Mediating Effect of Knowledge Sharing}

Innovation greatly depends on the effective use of acquired knowledge. Only when shared, integrated, and utilized through organizational learning, can an externally acquired knowledge be transformed into new products, technologies, and services to meet the needs of customers and improve the innovation performance of enterprises. Maskell [109] shows that the close network connection, mutual trust, and reciprocity between enterprises and external organizations can positively affect organizational learning and knowledge sharing, promote innovation activities, and enhance innovation capacity.

H4: Knowledge sharing mediates the relationship between intellectual capital and innovation performance.

Based on the above analysis, the conceptual model is established as shown in Figure 1.

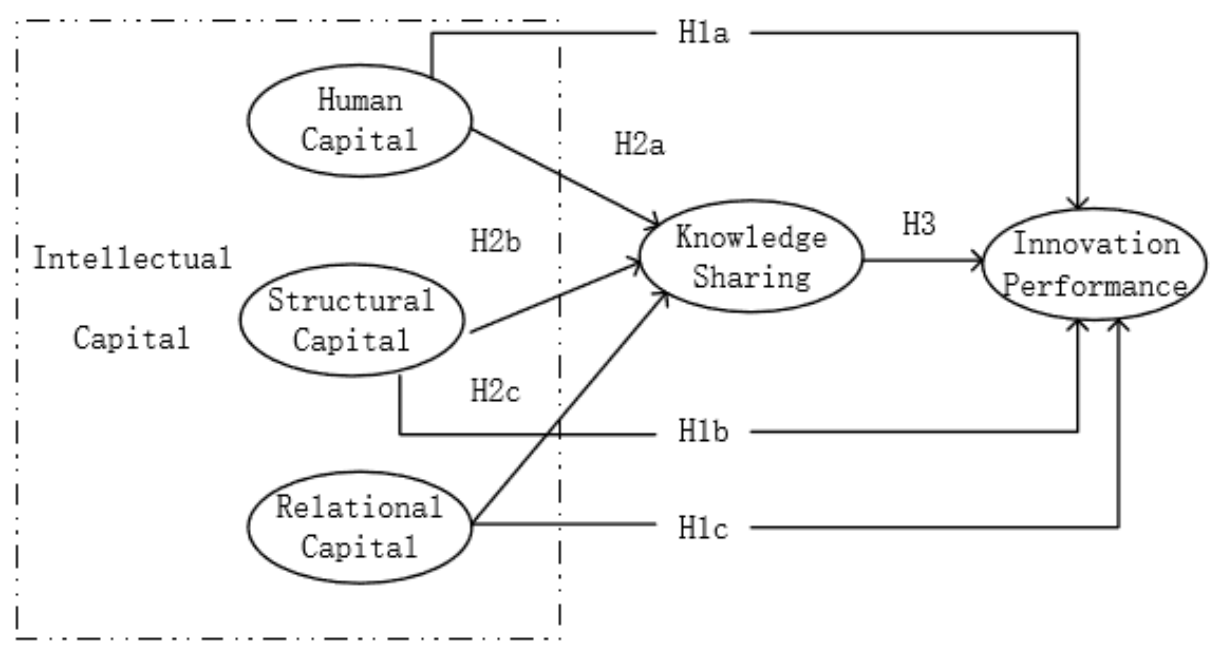

Figure 1. Conceptual Model. 


\section{Research Design}

\subsection{Sample and Data Collection}

A questionnaire survey was performed to collect the data for testing the validity of the model and the research hypotheses. The variables in this questionnaire include background information, intellectual capital, knowledge sharing, and innovation performance of the construction industry. Given that this study uses construction enterprises as its object, the target respondents of the survey included the managers and employees of construction enterprises in China.

This study selected large- and medium-sized construction enterprises to analyze the relationship among intellectual capital, knowledge sharing, and innovation performance. The surveyed enterprises were mainly located in Beijing, Shanghai, Shandong, Jiangsu, Zhejiang, and Guangdong. The questionnaire was mainly distributed in three ways, namely, through the Internet, through in-service postgraduate classes, and through enterprise visits. A total of 500 questionnaires have been distributed, and among the 213 returned questionnaires, 37 were discarded due to lack of responses and obvious deviations. The demographic information of the sample is presented in Table 1.

Table 1. Demographic information.

\begin{tabular}{cccc}
\hline Characteristic & Category & Frequency & Percentage \\
\hline \multirow{4}{*}{ Number of employees } & $<10$ & 1 & $0.57 \%$ \\
& $10-100$ & 36 & $20.45 \%$ \\
& $101-200$ & 45 & $25.57 \%$ \\
& $201-300$ & 37 & $21.02 \%$ \\
& $301-500$ & 39 & $22.16 \%$ \\
& $>500$ & 18 & $10.23 \%$ \\
Work experience & Total & 176 & 100.00 \\
& $\leq 5$ years & 26 & $14.77 \%$ \\
& $5-10$ years & 87 & $49.43 \%$ \\
& $>10$ years & 63 & $35.80 \%$ \\
& Total & 176 & 100.00 \\
\hline \multirow{3}{*}{ Designation } & Senior leader & 23 & $13.07 \%$ \\
& Project manager & 68 & $38.63 \%$ \\
& Knowledge employee & 85 & $48.30 \%$ \\
& Total & 176 & 100.00 \\
\hline
\end{tabular}

Among the participants, $69.73 \%$ were holding management positions in their enterprises, while the remaining $30.27 \%$ were knowledge-based employees who play important roles in the innovation development of their enterprises.

An exploratory factor analysis (EFA) was performed to evaluate the common method variance (CMV) of all multivariate items. Those five factors with eigenvalues exceeding 1 explain $69.72 \%$ of the total variance. A confirmatory factor analysis (CFA) was also performed on all those items with multiple-item variables by using the same data for evaluating CMV. In the CFA model, a single latent variable was connected to all items with multiple-item variables to calculate the model goodness-of-fit indices [110]. Given that the CFA model does not fit the data $\left(x^{2} / \mathrm{df}=6.49\right.$,comparative fit index $(\mathrm{CFI})=0.69<0.9$, adjusted goodness-of-fit index $(\mathrm{AGFI})=0.71<0.9$, and root mean square error of approximation $($ RMSEA $)=0.14>0.08)$, no single factor can account for most of the variance; in other words, no CMV is observed.

\subsection{Measurement}

The scales of all constructs in the questionnaire are based on the measurements of previous studies and were modified in this work based on the characteristics of the construction industry to ensure the content validity of the questionnaire. All measurement scales require five-point Likert-style responses ranging from "strongly disagree" to "strongly agree." The measurement items are presented in Table 2. 
Table 2. Validity and reliability assessment of the measures.

\begin{tabular}{|c|c|c|}
\hline Variable & Construct and Measuring Items & SFL \\
\hline \multicolumn{3}{|c|}{ Human capital: $\alpha=0.871 ; \mathrm{AVE}=0.591 ; \mathrm{CR}=0.651$} \\
\hline $\mathrm{HC} 1$ & The employees in my enterprise have excellent professional skills & 0.652 \\
\hline $\mathrm{HC} 2$ & The enterprise has a low employee turnover rate & 0.714 \\
\hline HC3 & The employees in my enterprise often take initiatives to discuss work matters with their colleagues and leaders & 0.749 \\
\hline $\mathrm{HC} 4$ & Leaders can properly arrange their employees' work and allocate resources & 0.805 \\
\hline \multicolumn{3}{|c|}{ Structural capital: $\alpha=0.897 ; \mathrm{AVE}=0.737 ; \mathrm{CR}=0.701$} \\
\hline SC1 & The enterprise has a good culture atmosphere of information exchange & 0.822 \\
\hline SC3 & The enterprise provides resources to support R\&D activities & 0.661 \\
\hline SC4 & The process and employee experience of the enterprise are incorporated into the database & 0.663 \\
\hline \multicolumn{3}{|c|}{ Relational capital: $\alpha=0.903 ; \mathrm{AVE}=0.715 ; \mathrm{CR}=0.639$} \\
\hline $\mathrm{RC} 1$ & My enterprise maintains long-term relationships with its customers & 0.813 \\
\hline $\mathrm{RC} 2$ & The enterprise often effectively cooperates with scientific research institutions & 0.714 \\
\hline $\mathrm{RC} 3$ & The enterprise effectively cooperates with experts or consultancies & 0.731 \\
\hline RC4 & My enterprise has strong strategic alliances & 0.674 \\
\hline KS1 & The enterprise often holds regular or irregular meetings within or between departments to disseminate work experience and methods & 0.746 \\
\hline KS2 & Experienced employees are encouraged to teach and mentor new employees & 0.653 \\
\hline KS3 & The enterprise often sends personnel on field trips or trainings for them to learn advanced technologies and management methods & 0.717 \\
\hline KS4 & The enterprise exchanges much knowledge about construction technology with cooperative enterprises. & 0.849 \\
\hline \multicolumn{3}{|c|}{ Innovation performance: $\alpha=0.899 ; \mathrm{AVE}=0.607 ; \mathrm{CR}=0.674$} \\
\hline IP1 & We have more patents and technical documentations compared with our peers & 0.718 \\
\hline IP2 & Compared with our main competitors, our enterprise can develop more efficient processes & 0.745 \\
\hline IP3 & The new product of the enterprise has received a positive market response & 0.826 \\
\hline IP4 & Compared with our main competitors, our enterprise has a strong and more advanced scientific research technology & 0.804 \\
\hline IP5 & Compared with our main competitors, our enterprise is often the first to introduce new products and services in the industry & 0.751 \\
\hline
\end{tabular}

Note: $\alpha=$ Cronbach's alpha; $\mathrm{AVE}=$ average variance extracted; and CR $=$ composite reliability. 
The three types of intellectual capital (i.e., human capital, structural capital, and relational capital) were measured by using the scales developed and validated by Bontis [43] and Hsu and Fang [111]. Specifically, these types of capital were measured by using a four-item scale that has been modified in this work accordingly.

Knowledge sharing was measured by using a five-item scale adapted from Darroch [112] and Szulanski [113].

Innovation performance was measured by using the five-item scale developed by Bell [114] and Ritter [115].

\section{Results and Discussion}

\subsection{Reliability and Validity}

To test structural reliability, a model was built by using the AMOS software to perform CFA on the data. The results of the model analysis (chi-square $\mathrm{x}^{2} / \mathrm{df}=2.754<3, \mathrm{CFI}=0.971>0.9$, and RMSEA $=0.069<0.08$ ) indicate that the fitting indexes of the structural equation model meet the requirements and show good fit with the data. The CFA results in Table 2 reveal that all standard factor loading (SFL) values exceed 0.5, the AVE values all exceed the 0.5 threshold, and the CR values of each construct exceed 0.6. Therefore, the scale shows good convergent reliability. Table 3 shows that the square root of the AVE of each construct exceeds the absolute value of the correlation coefficient between this construct and the other constructs, thereby indicating that the scale has good discriminant validity [116].

Table 3. Descriptive statistical analysis and correlation coefficients.

\begin{tabular}{|c|c|c|c|c|c|}
\hline Variables & Human Capital & Structural Capital & Relational Capital & Relational Capital & Relational Capital \\
\hline Human Capital & 0.768 & & & & \\
\hline Structural Capital & 0.563 & 0.858 & & & \\
\hline Relational Capital & 0.601 & 0.448 & 0.845 & & \\
\hline Innovation Performance & 0.621 & 0.584 & 0.467 & 0.484 & 0.779 \\
\hline Mean & 4.721 & 5.693 & 4.272 & 3.752 & 5.382 \\
\hline Standard deviation & 1.356 & 1.075 & 0.906 & 1.134 & 0.962 \\
\hline
\end{tabular}

Before testing the hypotheses, the internal consistency of the scale must be evaluated. SPSS21.0 was used to obtain the Cronbach's coefficient values of each variable. The results in Table 2 reveal that the Cronbach's coefficient values of all constructs are greater than 0.7 , thereby indicating that the questionnaire has a relatively high reliability [117].

\subsection{Hypothesis Testing}

The structural model of AMOS22.0 was used to test the hypotheses. The following goodness-of-fit statistics were obtained: chi-square $\mathrm{x}^{2} / \mathrm{df}=2.813<3 ; \mathrm{CFI}=0.945>0.9 ; \mathrm{IFI}=0.922>0.9 ; \mathrm{GFI}=0.934>$ 0.9 , and RMSEA $=0.071<0.08$.

Figure 2 and Table 4 presents the results of the model analysis and hypothesis tests. All three dimensions of intellectual capital significantly influence innovation performance, thereby supporting Hypothesis 1. Specifically, structural capital shows the greatest influence with $\beta=0.597(p<0.001)$, followed by human capital with $\beta=0.468(p<0.05)$ and relational capital with $\beta=0.359(p<0.05)$. These dimensions also positively affect knowledge sharing (with standardized coefficients of 0.375 , 0.571 , and 0.328 , respectively), thereby supporting Hypothesis 2 . The $p$ values of human capital and relational capital are both lower than 0.01 , while that of structural capital is less than 0.001 . A relationship was also observed between knowledge sharing and innovation performance $(\beta=0.412$ $(p<0.01))$, thereby supporting Hypothesis 3. 


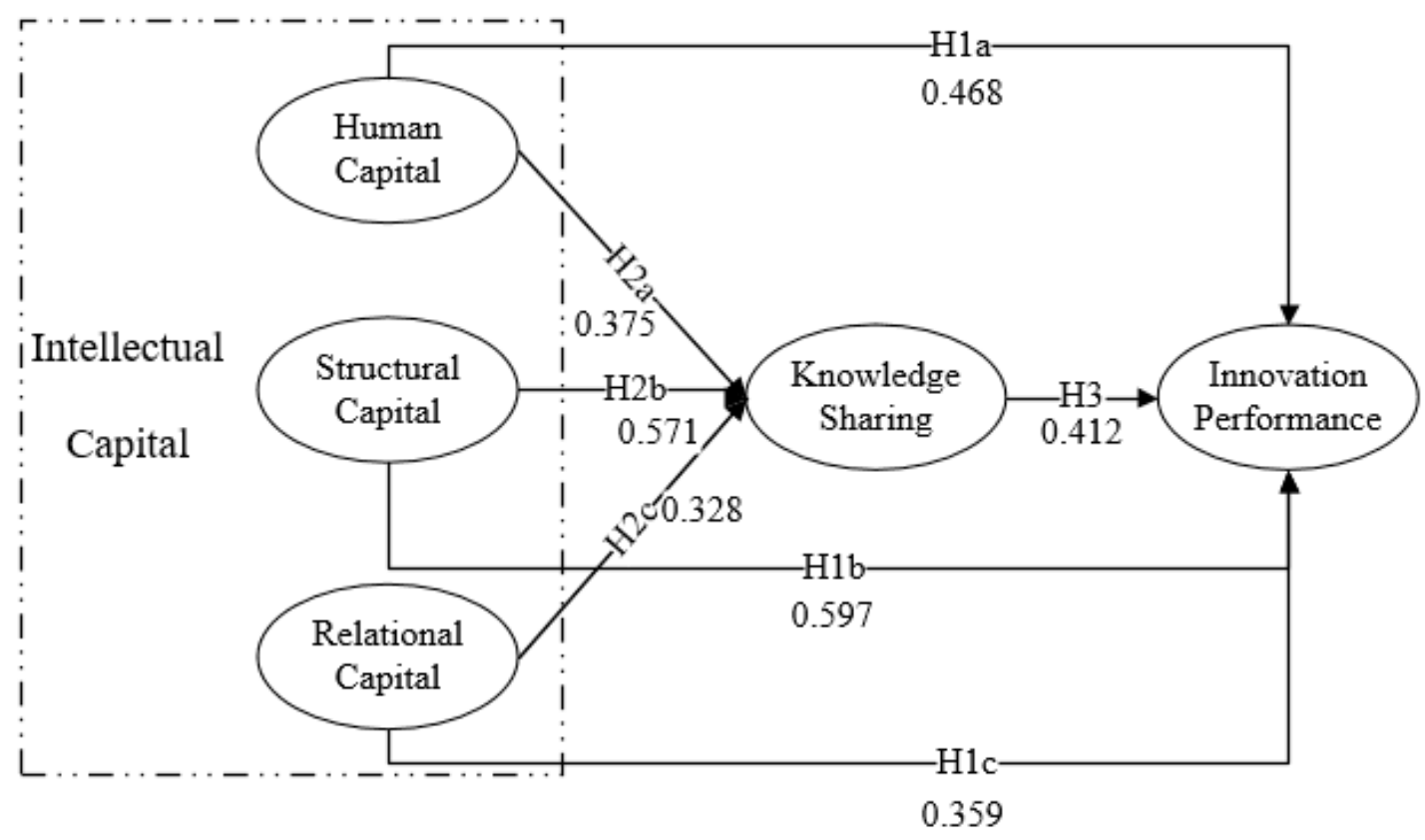

Figure 2. Structural model results.

Table 4. Structural model results.

\begin{tabular}{ccccc}
\hline Direct Effects & Hypothesis & Standardized Coefficients $(\boldsymbol{\beta})$ & $\boldsymbol{p}$-Value & Result \\
\hline $\mathrm{HC} \rightarrow \mathrm{IP}$ & $\mathrm{H} 1 \mathrm{a}$ & 0.468 & $*$ & Supported \\
\hline $\mathrm{SC} \rightarrow \mathrm{IP}$ & $\mathrm{H} 1 \mathrm{~b}$ & 0.597 & $* * *$ & Supported \\
\hline $\mathrm{RC} \rightarrow \mathrm{IP}$ & $\mathrm{H} 1 \mathrm{c}$ & 0.359 & $*$ & Supported \\
\hline $\mathrm{HC} \rightarrow \mathrm{KS}$ & $\mathrm{H} 2 \mathrm{a}$ & 0.375 & $* *$ & Supported \\
\hline $\mathrm{SC} \rightarrow \mathrm{KS}$ & $\mathrm{H} 2 \mathrm{~b}$ & 0.571 & $* * *$ & Supported \\
\hline $\mathrm{RC} \rightarrow \mathrm{KS}$ & $\mathrm{H} 2 \mathrm{c}$ & 0.328 & $*$ Supported \\
\hline $\mathrm{KS} \rightarrow \mathrm{IP}$ & $\mathrm{H} 3$ & 0.412 & Supported \\
\hline
\end{tabular}

One purpose of this study is to test the mediating effect of knowledge sharing on the relationship between intellectual capital and innovation performance. Such mediating effect was tested based on the method proposed by Baron [118], which requires the following conditions to be met: (1) The initial variable (intellectual capital) must be correlated with the outcome variable (innovation performance); (2) the initial variable (intellectual capital) must be significantly correlated with the mediator (knowledge sharing); (3) the mediator (knowledge sharing) must affect the outcome variable (innovation performance); and (4) the effect of the initial variable (intellectual capital) on the outcome variable (innovation performance) decreases in both significance and magnitude when the mediator is added to the model.

The results of the mediating effect test are presented in Table 5.

Table 5. Analysis of the mediating effect test results.

\begin{tabular}{cccc}
\hline Relation & Direct Effect Without Mediator & Direct Effect with Mediator & Result \\
\hline HC-KS-IP & $0.623, p<0.001$ & $0.468, p<0.05$ & Partial mediation \\
SC-KS-IP & $0.734, p<0.001$ & $0.597, p<0.001$ & Partial mediation \\
RC-KS-IP & $0.408, p<0.001$ & $0.359, p<0.05$ & Partial mediation \\
\hline
\end{tabular}


As shown in Table 5, knowledge sharing has a partial mediating effect on the relationship between intellectual capital and innovation performance, thereby supporting Hypothesis 4 .

\subsection{Discussion}

The main purpose of this study is to examine the role of intellectual capital in promoting the innovation performance of construction enterprises and the role of knowledge sharing as a possible intervening mechanism that mediates the relationship between intellectual capital and innovation performance. As predicted, intellectual capital is positively related to innovation performance and knowledge sharing partially mediates such relationship.

Using the structural equation model to examine the relationship among intellectual capital, knowledge sharing, and innovation performance in the construction industry yields the following conclusions.

\subsubsection{Intellectual Capital and Knowledge Sharing}

The three dimensions of intellectual capital significantly affect knowledge sharing. This finding is interesting given that previous studies have focused on the relationship between intellectual capital and knowledge management and have completely ignored the relationship between intellectual capital and knowledge sharing, which is an important dimension of knowledge management. Structural capital shows the greatest influence on knowledge sharing. This finding is similar to that of Abzari and Teimouri [97], who find that information systems and technologies and organization structure positively affect the sharing of knowledge within organizations. Ismail, et al. add that among the many factors that promote knowledge sharing, organization culture shows the most significant influence [98]. According to Zin and Egbu [95], those factors that promote knowledge sharing mainly include structural capital elements (e.g., organizational infrastructure, standard, flexible knowledge structures, and knowledge-friendly culture), human capital elements (e.g., formal education and training), and relational capital elements (e.g., interaction with clients and suppliers), which has been identified and examined in this work.

\subsubsection{Intellectual Capital, Knowledge Sharing, and Innovation Performance}

Human capital, structural capital, and relational capital all have significant positive effects on the innovation performance of the construction industry, thereby supporting Hypothesis 1 . This result is consistent with the findings of Zerenler, et al. [1], who argue that intellectual capital is an important factor for improving the innovation performance of construction enterprises in China.

Consistent with the findings of Kianto, et al. [42], structural capital has significant positive effects on innovation performance. In addition, the analysis results reveal that structural capital has the greatest influence on innovation performance $(\beta=0.597, p<0.001)$, possibly due to the fact that structural capital is a basic element of intellectual capital and that corporate culture is a core part of an enterprise that determines its future development. The accumulation and application of patents and institutionalized knowledge by construction enterprises can help them expand their existing knowledge and realize innovation in the form of new patents and awards, which in turn can help them enhance their innovation ability and performance. The organizational structure, rules and regulations, construction processes, and engineering construction environments of construction enterprises also provide a solid basis for their smooth operations. Corporate culture provides a platform for promoting communication and exchange among employees, helping these employees accumulate architectural knowledge, construction experiences, and professional know-how in a positive work atmosphere, and promoting harmonious relationships among construction project teams. Intangible capital, such as intellectual property rights, greatly improves the engineering construction strength of construction enterprises and provides the basic conditions for improving their innovation performance.

Human capital positively affects innovation performance $(\beta=0.468, p<0.05)$. This finding is in line with the conclusions of Barczak and Wilemon [119], who argue that the professional skills, 
experiences, managerial capabilities, and creativity of employees and innovation project managers can positively affect innovation performance. As a core element of enterprise innovation, employees have a significant influence on enterprise innovations, while their strong working ability is highly conducive to promoting enterprise innovation. Strengthened connections can also provide enterprises with a large amount of external knowledge and technologies as well as help them obtain sufficient information resources to promote their innovation performance.

Relational capital has the least impact on the innovation performance $(\beta=0.359, p<0.05)$, which contradicts the conclusions of Zerenler, et al. [1]. Such inconsistency may be explained by the characteristics of construction enterprise. In China, construction enterprises focus on innovation, which mainly requires the efforts of members in construction sites than that of other groups outside the project department. Although relational capital is considered a necessity for enterprises, this resource alone may not be enough for construction enterprises to achieve innovation performance.

As an important external resource, relationship capital determines the smooth progress of projects undertaken by construction enterprises. Construction enterprises must build their trust and commitment with other project-related parties and promote an effective conflict management to reduce unnecessary frictions in their communication and cooperation processes and to facilitate the exchange of important knowledge and resources that can help them achieve innovation.

Consistent with the findings of previous studies, knowledge sharing positively affects innovation performance ( $\beta=0.412, p<0.01$ ). Wang [120] argues that knowledge sharing is positively associated with innovation performance and proposes that managers must highlight the importance of knowledge sharing to enhance the innovation performance of their enterprises. Qammach [106] adds that knowledge sharing is positively related to innovation performance. This result emphasizes the importance of knowledge sharing in promoting the innovation performance of the construction industry.

\subsubsection{Mediating Effect of Knowledge Sharing}

A comparison of those models with and without the mediating effect reveals that the three dimensions of intellectual capital have a significant influence on innovation performance, but their corresponding weight coefficients are reduced when the mediating effect of knowledge sharing is considered. In other words, intellectual capital can promote the innovation performance of construction enterprises through knowledge sharing. Therefore, construction enterprises must underscore the role of knowledge sharing, tap on their intellectual capital, and constantly improve their innovation performance by making full use of their intellectual capital and knowledge sharing.

\section{Conclusions and Suggestions}

\subsection{Implications}

By reviewing the literature and examining the characteristics and background of construction enterprises, this study establishes a theoretical model for examining the relationship among intellectual capital, knowledge sharing, and enterprise innovation performance. An empirical analysis is conducted to verify the relationship among these factors and to provide some practical knowledge and suggestions for construction enterprises to improve their innovation performance.

This empirical work reveals that the three dimensions of intellectual capital not only have direct and positive effects on innovation performance, but also promote innovation performance through knowledge sharing. Among these dimensions, structural capital plays the most important role in promoting knowledge sharing and improving the innovation performance of enterprises, thereby suggesting that the culture and system of an enterprise plays an important role in promoting innovation and a knowledge sharing atmosphere. Therefore, to improve innovation performance, construction enterprises must improve their structural capital. They can establish a shared enterprise culture and encourage their employees to share knowledge, especially among experienced engineers whose ideas collide throughout a project. Establishing a knowledge database can also facilitate the transfer 
and sharing of cross-disciplinary knowledge. In addition, patent analysis has become a new area of construction innovation, and construction enterprises can establish public patent databases as knowledge sources to achieve technology innovation [121].

Human capital shows a significant positive impact on the knowledge sharing and innovation performance of enterprises, thereby suggesting that high-quality human resources are key elements for sharing and innovation. However, construction enterprises generally have a widespread special operating environment, and their employees generally have poor work quality and knowledge. Therefore, to enhance their innovation performance, these enterprises must accelerate their training of talents and promote the generation of new ideas by encouraging knowledge exchange and sharing during the implementation of their projects. The competition among employees in the construction industry may also hinder the sharing of knowledge within an enterprise. Therefore, effective incentive mechanisms, such as technology investments, paid enjoyment of achievements, reasonable reward systems, and relevant treatments, must be established to ensure that the individual value of employees is acknowledged and to motivate these employees to share knowledge with one another [122]. The construction industry is currently facing a transition period, and prefabricated buildings and green buildings have become a future development direction for this industry. Along with the reform of this industry, the government has implemented standardized requirements on the operation of construction enterprises. To achieve a long-term development, these enterprises must introduce knowledge-based employees, increase their human capital, and offer innovation opportunities. They should also organize regular trainings for their employees to help them develop a sense of innovation and accept new ideas [123]. Chinese construction enterprises tend to attach importance to the skills of project managers while ignoring their soft skills related to sustainability, and this problem can be alleviated by implementing relevant government policies (e.g., issuing soft skills licenses). These enterprises must also cultivate the soft skills of their project managers.

Group efforts within the construction industry must also be strengthened given that some innovative projects in this industry often involve people from different majors, disciplines, units, and departments. Therefore, construction enterprises must also focus on the joint tackling of problems and the sharing of benefits among employees.

\subsection{Limitations and Directions for Future Research}

This study has several limitations that require further examination. First, this study takes construction enterprises as its research object, and future work can test the relationship among the intellectual capital, knowledge sharing, and innovation performance of enterprises from other industries or countries. Second, this study uses a questionnaire to collect data from project managers, engineers, and other internal knowledge employees, but the data collected using this instrument may be highly subjective. Future studies may use objective indicators to retest the proposed hypotheses. Third, the research hypotheses are tested by performing a questionnaire survey, which only provides horizontal data. Future work may perform a longitudinal study to identify the differences in the intellectual capital of construction enterprises. Fourth, technological innovation is the main breakthrough point of project innovation in construction enterprises. Future studies may narrow the scope of innovation performance to technological innovation performance. Fifth, future studies may examine other mediators of the relationship between intellectual capital and enterprise innovation performance to deepen our understanding of how intellectual capital affects the innovation performance of construction enterprises.

Author Contributions: Y.S. conceived and designed the study, performed the data analysis, and wrote the draft of the manuscript. Y.L. and J.W. revised the manuscript. C.L. collected the data. All authors have read and approved the submitted version.

Funding: This research received no external funding.

Conflicts of Interest: The authors declare no conflicts of interest. 


\section{References}

1. Zerenler, M.; Hasiloglu, S.B.; Sezgin, M. Intellectual Capital and Innovation Performance: Empirical Evidence in the Turkish Automotive Supplier. J. Technol. Manag. 2008, 3, 31-40. [CrossRef]

2. Kamasak, R. Determinants of innovation Performance: A Resource-based Study. Procedia Soc. Behv. 2015, 195, 1330-1337. [CrossRef]

3. Buenechea-Elberdin, M.; Sáenz, J.; Kianto, A. Exploring the role of human capital, renewal capital and entrepreneurial capital in innovation performance in high-tech and low-tech firms. Knowl. Manag. Res. Pract. 2017, 15, 369-379. [CrossRef]

4. Chen, C.J.; Huang, J.W. Strategic human resource practices and innovation performance-The mediating role of knowledge management capacity. J. Bus. Res. 2009, 62, 104-114. [CrossRef]

5. Rajapathirana, R.P.J.; Hui, Y. Relationship between innovation capability, innovation type, and firm performance. J. Innov. Knowl. 2018, 3, 44-55. [CrossRef]

6. Gima, K.A.; Murray, J.Y. Exploratory and Exploitative Learning in New Product Development: A Social Capital Perspective on New Technology Ventures in China. J. Int. Mark. 2007, 15, 1-29. [CrossRef]

7. Miron, E.; Erez, M.; Naveh, E. Do personal characteristics and cultural values that promote innovation, quality, and efficiency compete or complement each other? J. Organ. Behav. 2004, 25, 175-199. [CrossRef]

8. Silvestre, B.S.; Tुîrcă, D.M. Innovations for sustainable development: Moving toward a sustainable future. J. Clean. Prod. 2019, 208, 325-332. [CrossRef]

9. Zhang, J.; Li, H.; Wang, S.H.-M. Analysis and Potential Application of the Maturity of Growth Management in the Developing Construction Industry of a Province of China: A Case Study. Sustainability 2017, 9, 143. [CrossRef]

10. Segarra-Ona, M.D.; Peiro-Signes, A.; Cervello-Royo, R. A Framework to Move Forward on the Path to Eco-innovation in the Construction Industry: Implications to Improve Firms' Sustainable Orientation. Sci. Eng. Ethics 2015, 21, 1469-1484. [CrossRef]

11. Gogan, L.M.; Artene, A.; Sarca, I.; Draghici, A. The Impact of Intellectual Capital on Organizational Performance. Procedia Soc. Behv. 2016, 221, 194-202. [CrossRef]

12. Hervas-Oliver, J.L.; Rojas, R.; Martins, B.M.; Cervelló-Royo, R. The overlapping of national IC and innovation systems. J. Intellect. Cap. 2011, 12, 111-131. [CrossRef]

13. Ahmad, S.b.; Mushraf, A.M. The Relationship between Intellectual capital and Business Performance: An empirical study in Iraqi industry. In Proceedings of the International Conference on Management and Artificial Intelligence, Bali, Indonesia, 1-3 April 2011; pp. 104-109.

14. Edvinsson, L.; Malone, M.S. Intellectual Capital: Realizing Your Company's True Value by Finding Its Hidden Brainpower; Harper Business: New York, NY, USA, 1997.

15. Egbu, C.O. Managing knowledge and intellectual capital for improved organizational innovations in the construction industry: An examination of critical success factors. Eng. Constr. Archit. Manag. 2004, 11, 301-315. [CrossRef]

16. Nowacki, R.; Bachnik, K. Innovations within knowledge management. J. Bus. Res. 2016, 69, $1577-1581$. [CrossRef]

17. Shujahat, M.; Sousa, M.J.; Hussain, S.; Nawaz, F.; Wang, M.; Umer, M. Translating the impact of knowledge management processes into knowledge-based innovation: The neglected and mediating role of knowledge-worker productivity. J. Bus. Res. 2019, 94, 442-450. [CrossRef]

18. Wu, S.; Lin, L.; Hsu, M. Intellectual capital, dynamic capabilities and innovative performance of organisations. Int. J. Technol. Manag. 2007, 39, 279-296. [CrossRef]

19. Yeşil, S.; Koska, A.; Büyükbeşe, T. Knowledge Sharing Process, Innovation Capability and Innovation Performance: An Empirical Study. Procedia Soc. Behv. 2013, 75, 217-225. [CrossRef]

20. Bai, J. On Regional Innovation Efficiency: Evidence from Panel Data of China's Different Provinces. Reg. Stud. 2013, 47, 773-788. [CrossRef]

21. Noktehdan, M.; Shahbazpour, M.; Wilkinson, S. Driving Innovative Thinking in the New Zealand Construction Industry. Buildings 2015, 5, 297-309. [CrossRef]

22. Badu, E.; Owusu-Manu, D.-G.; Edwards, D.J.; Holt, G.D. Analysis of Strategic Issues Underpinning the Innovative Financing of Infrastructure within Developing Countries. J. Constr. Eng. Manag. 2013, 139, 726-737. [CrossRef] 
23. Lizarralde, G.; Tomiyoshi, S.; Bourgault, M.; Malo, J.; Cardosi, G. Understanding differences in construction project governance between developed and developing countries. Constr. Manag. Econ. 2013, 31, 711-730. [CrossRef]

24. Serpell, A.; Alvarez, R. A Systematic Approach for Evaluating Innovation Management in Construction Companies. Procedia Eng. 2014, 85, 464-472. [CrossRef]

25. Scaringella, L.; Burtschell, F. The challenges of radical innovation in Iran: Knowledge transfer and absorptive capacity highlights-Evidence from a joint venture in the construction sector. Technol. Forecast. Soc. Chang. 2017, 122C, 151-169. [CrossRef]

26. Dumay, J. 15 years of theJournal of Intellectual Capitaland counting. J. Intellect. Cap. 2014, 15, 2-37. [CrossRef]

27. Petty, R.; Guthrie, J. Intellectual capital literature review: Measurement, reporting and management. J. Intellect. Cap. 2000, 1, 155-176. [CrossRef]

28. Boedker, C.; Mouritsen, J.; Guthrie, J. Enhanced business reporting: International trends and possible policy directions. J. Hum. Resour. Costing Account. 2008, 12, 14-25. [CrossRef]

29. Dumay, J.; Dumay, J.; Garanina, T. Intellectual capital research: A critical examination of the third stage. J. Intellect. Cap. 2013, 14, 10-25. [CrossRef]

30. Guthrie, J.; Ricceri, F.; Dumay, J. Reflections and projections: A decade of Intellectual Capital Accounting Research. Br. Account. Rev. 2012, 44, 68-82. [CrossRef]

31. Dumay, J. The third stage of IC: Towards a new IC future and beyond. J. Intellect. Cap. 2013, 14, 5-9. [CrossRef]

32. Nahapiet, J.; Ghoshal, S. Social capital, intellectual capital, and the organizational advantage. Acad. Manag. Rev. 1998, 23, 242-266. [CrossRef]

33. Youndt, M.A.; Subramaniam, M.; Snell, S.A. Intellectual Capital Profiles:An Examination of Investments and Returns. J. Manag. Stud. 2004, 41, 335-361. [CrossRef]

34. Johnson, W. Integrative taxonomy of intellectual capital: Measuring the stock and flow of intellectual capital components in the firm. Int. J. Technol. Manag. 1999, 18. [CrossRef]

35. Herremans, I.M.; Isaac, R.G.; Kline, T.J.B.; Nazari, J.A. Intellectual Capital and Uncertainty of Knowledge: Control by Design of the Management System. J. Bus. Ethics 2010, 98, 627-640. [CrossRef]

36. Roos, G.; Roos, J. Measuring Your Company's Intellectual Performance. Long Range Plan. 1997, 30, 413-426.

37. Sharabati, A.A.A.; Naji Jawad, S.; Bontis, N. Intellectual capital and business performance in the pharmaceutical sector of Jordan. Manag. Decis. 2010, 48, 105-131. [CrossRef]

38. Stewart, T.; Ruckdeschel, C. Intellectual capital: The new wealth of organizations. Perform. Improv. 1998, 37, 56-59. [CrossRef]

39. Reed, K.K.; Lubatkin, M.; Srinivasan, N. Proposing and testing an intellectual capital-based view of the firm.pdf. J. Manag. Stud. 2006, 43, 867-893. [CrossRef]

40. Bontis, N. Intellectual capital:an exploratory study that develops measures and models. Manag. Decis. 1998, 36, 63-76. [CrossRef]

41. Schultz, T.W. Investment in Human Capital. Am. Econ. Rev. 1961, 51, 1-17.

42. Kianto, A.; Sáenz, J.; Aramburu, N. Knowledge-based human resource management practices, intellectual capital and innovation. J. Bus. Res. 2017, 81, 11-20. [CrossRef]

43. Bontis, N.; Chua Chong Keow, W.; Richardson, S. Intellectual Capital and Business Performance in Malaysian Industry. J. Intellect. Cap. 2000, 1, 85-100. [CrossRef]

44. Cabrita, M.d.R.; Bontis, N. Intellectual capital and business performance in the Portuguese banking industry. Int. J. Technol. Manag. 2008, 43, 212-237. [CrossRef]

45. Youndt, M.A.; Snell, S.A. Human Resource Configurations, Intellectual Capital, and Organizational Performance. J. Manag. Issues 2004, 337-360.

46. Marr, B.; Roos, G. A strategy perspective on intellectual capital. Perspect. Intell. 2005, 28-52. [CrossRef]

47. Januškaitė, V.; Užienè, L. Intellectual Capital as a Factor of Sustainable Regional Competitiveness. Sustainability 2018, 10, 4848. [CrossRef]

48. Phusavat, K.; Comepa, N.; Sitko-Lutek, A.; Ooi, K.B. Interrelationships between intellectual capital and performance: Empirical examination. Ind. Manag. Data Syst. 2011, 111, 810-829. [CrossRef]

49. Agostini, L.; Nosella, A.; Filippini, R. Does intellectual capital allow improving innovation performance? A quantitative analysis in the SME context. J. Intellect. Cap. 2017, 18, 400-418. [CrossRef]

50. Grant, R.M. Toward a knowledge-based theory of the firm. Strateg. Manag. J. 1996, 17, 109-122. [CrossRef] 
51. Suppiah, V.; Singh Sandhu, M. Organisational culture's influence on tacit knowledge sharing behaviour. J. Knowl. Manag. 2011, 15, 462-477. [CrossRef]

52. Inkinen, H. Review of empirical research on knowledge management practices and firm performance. J. Knowl. Manag. 2016, 20, 230-257. [CrossRef]

53. Faraj, I.; Alshawi, M.; Aouad, G.; Child, T.; Underwood, J. Distributed object environment: Using international standards for data exchange in the construction industry. Comput. Aided Civ. Infrastruct. Eng. 1999, 14, 395-405. [CrossRef]

54. Kamara, J.M.; Anumba, C.J.; Carrillo, P.M. Integration of Knowledge Management Within Construction Business Process. In Proceedings of the UK National Conference on Objects and Integration for Architecture, Engineering and Construction: Building Research Establishment Ltd., London, UK, 13-14 March 2000; pp. 95-105.

55. Sabherwal, R.; Becerra-Fernandez, I. An Empirical Study of the Effect of Knowledge Management Processes at Individual, Group, and Organizational Levels. Decis. Sci. 2003, 34, 225-260. [CrossRef]

56. Boddy, S.; Rezgui, Y.; Cooper, G.; Wetherill, M. Computer integrated construction: A review and proposals for future direction. Adv. Eng. Softw. 2007, 38, 677-687. [CrossRef]

57. Ibrahim, Y.M.; Lukins, T.C.; Zhang, X.; Trucco, E.; Kaka, A.P. Towards automated progress assessment of workpackage components in construction projects using computer vision. Adv. Eng. Inform. 2009, 23, 93-103. [CrossRef]

58. Teizer, J.; Vela, P.A. Personnel tracking on construction sites using video cameras. Adv. Eng. Inform. 2009, 23, 452-462. [CrossRef]

59. Lee, V.H.; Leong, L.Y.; Hew, T.S.; Ooi, K.B. Knowledge management: A key determinant in advancing technological innovation? J. Knowl. Manag. 2013, 17, 848-872. [CrossRef]

60. Wen, Q.; Qiang, M. Coordination and knowledge sharing in construction project-based organization: A longitudinal structural equation model analysis. Autom. Constr. 2016, 72, 309-320. [CrossRef]

61. Lin, H.F. Knowledge sharing and firm innovation capability: An empirical study. Int. J. Manpow. 2007, 28, 315-332. [CrossRef]

62. Zhang, X.; Mao, X.; AbouRizk, S.M. Developing a knowledge management system for improved value engineering practices in the construction industry. Autom. Constr. 2009, 18, 777-789. [CrossRef]

63. Rodney, M.; McCreedy, S. A critical review of knowledge management models. Learn. Org. 1999, 6, 91-101. [CrossRef]

64. Zbuchea, A.; Pînzaru, F.; Busu, M.; Stan, S.-O.; Bârgăoanu, A. Sustainable Knowledge Management and Its Impact on the Performances of Biotechnology Organizations. Sustainability 2019, 11, 359. [CrossRef]

65. Badii, A.; Sharif, A. Information management and knowledge integration for enterprise innovation. Logist. Inform. Man. 2003, 16, 145-155. [CrossRef]

66. Chen, J.; Zhu, Z.; Xie, H.Y. Measuring intellectual capital: A new model innovativeness and performance. J. Bus. Res. 2004, 60, 566-575.

67. Rogers, E.M. Diffusion of Innovations; The Free Pres: New York, NY, USA, 1995; ISBN 978-0028740744.

68. Kline, S.J.; Rosenberg, N. An overview of innovation. Stud. Sci. Innov. 2010, 173-203. [CrossRef]

69. Manual, O. Guidelines for Collecting and Interpreting Innovation Data, 3rd ed.; OECD and Statistical Office of the European Communities: Paris, France, 2005. [CrossRef]

70. Liu, G.; Li, K.; Zhao, D.; Mao, C. Business Model Innovation and Its Drivers in the Chinese Construction Industry during the Shift to Modular Prefabrication. J. Manag. Eng. 2016, 33. [CrossRef]

71. Loosemore, M.; Richard, J. Valuing innovation in construction and infrastructure. Eng. Constr. Archit. Manag. 2015, 22, 38-53. [CrossRef]

72. Xue, X.; Zhang, R.; Yang, R.; Dai, J. Innovation in Construction: A Critical Review and Future Research. Int. J. Innov. Sci. 2014, 6, 111-126. [CrossRef]

73. Spender, J.C. Making knowledge the basis of a dynamic theory of the firm. Strateg. Manag. J. 1996, 17, 45-62. [CrossRef]

74. Wang, Z.; Wang, N.; Cao, J.; Ye, X. The impact of intellectual capital-Knowledge management strategy fit on firm performance. Manag. Decis. 2016, 54, 1861-1885. [CrossRef]

75. Marina, D.P. The role of knowledge management in innovation. J. Knowl. Manag. 2007, 11, 20-29. [CrossRef]

76. Sydler, R.; Haefliger, S.; Pruksa, R. Measuring intellectual capital with financial figures: Can we predict firm profitability? Eur. Manag. J. 2014, 32, 244-259. [CrossRef] 
77. Chen, C.J.; Liu, T.C.; Chu, M.A.; Hsiao, Y.C. Intellectual capital and new product development. J. Eng. Technol. Manag. 2014, 33, 154-173. [CrossRef]

78. Wang, Z.; Wang, N. Knowledge sharing, innovation and firm performance. Expert Syst. Appl. 2012, 39, 8899-8908. [CrossRef]

79. Kannan, G.; Aulbur, W.G. Intellectual capital: Measurement effectiveness. J. Intellect. Cap. 2004, 5, $389-413$. [CrossRef]

80. Brooking, A. Intellectual Capital Core Asset for Third Millenium Enterprise; Thomson Publishing: Boston, MA, USA, 1996; ISBN 978-1861524089.

81. De Winne, S.; Sels, L. Interrelationships between human capital, HRM and innovation in Belgian start-ups aiming at an innovation strategy. Int. J. Hum. Resour. Manag. 2010, 21, 1863-1883. [CrossRef]

82. Teece, D.J. Firm organization, industrial structure, and technological innovation. J. Econ. Behav. Organ. 1996, 31, 193-224. [CrossRef]

83. Lin, Y.C.; Lee, H.Y. Developing project communities of practice-based knowledge management system in construction. Autom. Constr. 2012, 22, 422-432. [CrossRef]

84. Dyer, J.H.; Hatch, N.W. Relation-specific capabilities and barriers to knowledge transfers: Creating advantage through network relationships. Strateg. Manag. J. 2006, 27, 701-719. [CrossRef]

85. Liu, C.L.; Ghauri, P.N.; Sinkovics, R.R. Understanding the impact of relational capital and organizational learning on alliance outcomes. J. World. Bus. 2010, 45, 237-249. [CrossRef]

86. Ghorbani, M. Study of the relationship between intellectual capital management and organizational innovation in the banks. Afr. J. Bus. Manag. 2012, 6. [CrossRef]

87. Sulistyo, H. Innovation capability of SMEs through entrepreneurship, marketing capability, relational capital and empowerment. Asia Pac. Manag. 2016, 21, 196-203. [CrossRef]

88. Tsai, M.T.; Tsa, C.L. Innovation capability and performance in Taiwanese science Parks:Exploring the moderating effects of industrial clusters fabric. Int. J. Org. Innov. 2000, 2, 80-103.

89. Heisig, P. Harmonisation of knowledge management-Comparing $160 \mathrm{KM}$ frameworks around the globe. J. Knowl. Manag. 2009, 13, 4-31. [CrossRef]

90. Obeidat, B.Y.; Tarhini, A.; Masa'deh, R.e.; Aqqad, N.O. The impact of intellectual capital on innovation via the mediating role of knowledge management: A structural equation modelling approach. Int. J. Knowl. Manag. Stud. 2017, 8, 273-298. [CrossRef]

91. Brown, J.R.; Lusch, R.F.; Nicholson, C.Y. Power and relationship commitment: Their impact on marketing channel member performance. J. Retail. 1995, 71, 363-392. [CrossRef]

92. Chan, I.; Chau, P.Y. Getting knowledge management right: Lessons from failure. Int. J. Knowl. Manag. 2005, 1, 40-54. [CrossRef]

93. Laupase, R. The Process of Converting Consultants' Tacit Knowledge to Organisational Explicit Knowledge: Case Studies in Management Consulting Firms; IGI Global: Hershey, PA, USA, 2003; pp. 212-225.

94. Byrne, R.J. Employees: Capital or commodity? Learn. Org. 2001, 8, 44-50. [CrossRef]

95. Zin, M.; Egbu, C.O. A Review of Knowledge Management Strategies-Issues, Contexts and Benefits for the Construction Industry. In Proceedings of the CIB World Congress 2010, The Lowry, Salford Quays, UK, 10-13 May 2010.

96. De Long, D.W.; Fahey, L. Diagnosing cultural barriers to knowledge management. Acad. Manag. Pers. 2000, 14, 113-127. [CrossRef]

97. Abzari, M.; Teimouri, H. The effective factors on knowledge sharing in organizations. Int. J. Knowl. Cult. 2008, 8, 105-113. [CrossRef]

98. Ismail Al-Alawi, A.; Yousif Al-Marzooqi, N.; Fraidoon Mohammed, Y. Organizational culture and knowledge sharing: Critical success factors. J. Knowl. Manag. 2007, 11, 22-42. [CrossRef]

99. Hsu, I.C.; Sabherwal, R. Relationship between intellectual capital and knowledge management: An empirical investigation. Decis. Sci. 2012, 43, 489-524. [CrossRef]

100. $\mathrm{Mu}, \mathrm{J} . ;$ Benedetto, C.A.D. Strategic orientations and new product commercialization: Mediator, moderator, and interplay. RD Manag. 2011, 41, 337-359. [CrossRef]

101. Dyer, J.H.; Nobeoka, K. Creating and managing a high-performance knowledge-sharing network: The Toyota case. Strateg. Manag. J. 2000, 21, 345-367. [CrossRef]

102. Krishnan, R.; Martin, X.; Noorderhaven, N.G. When does trust matter to alliance performance? Acad. Manag. J. 2006, 49, 894-917. [CrossRef] 
103. Chiang, Y.H.; Hung, K.P. Exploring open search strategies and perceived innovation performance from the perspective of inter-organizational knowledge flows. RD Manag. 2010, 40, 292-299. [CrossRef]

104. Gächter, S.; von Krogh, G.; Haefliger, S. Initiating private-collective innovation: The fragility of knowledge sharing. Res. Policy 2010, 39, 893-906. [CrossRef]

105. Homans, G.C. Social Behavior as Exchange. Am. J. Sociol. 1958, 63, 597-606. [CrossRef]

106. Qammach, N.I.J. The Mediating Role of Knowledge Sharing on Relationship between IT Capability and IT Support as Predictors of Innovation Performance: An Empirical Study on Mobile Companies in Iraq. Proc. Econ. Financ. 2016, 39, 562-570. [CrossRef]

107. Heffner, M.; Sharif, N. Knowledge fusion for technological innovation in organizations. J. Knowl. Manag. 2008, 12, 79-93. [CrossRef]

108. Lundvall, B.Å.; Svetlik, I.; Nielsen, P. Knowledge management and innovation performance. Int. J. Manpow. 2007, 28, 207-223. [CrossRef]

109. Maskell, P. Social Capital, Innovation, and Competitiveness. In Social Capital: Critical Perspectives; Baron, S., Field, J., Schuller, T., Eds.; Oxford University Press: Oxford, UK, 2000; pp. 111-123.

110. Podsakoff, P.M.; MacKenzie, S.B.; Lee, J.-Y.; Podsakoff, N.P. Common method biases in behavioral research: A critical review of the literature and recommended remedies. J. Appl. Psychol. 2003, 88, 879. [CrossRef]

111. Hsu, Y.H.; Fang, W. Intellectual capital and new product development performance: The mediating role of organizational learning capability. Technol. Forecast. Soc. Chang. 2009, 76, 664-677. [CrossRef]

112. Darroch, J. Developing a measure of knowledge management behaviors and practices. J. Knowl. Manag. 2003, 7, 41-54. [CrossRef]

113. Szulanski, G. Exploring internal stickiness: Impediments to the transfer of best practice within the firm. Strateg. Manag. J. 1996, 17, 27-43. [CrossRef]

114. Bell, G.G. Clusters, networks, and firm innovativeness. Strateg. Manag. J. 2005, 26, 287-295. [CrossRef]

115. Ritter, T.; Gemünden, H.G. The impact of a company's business strategy on its technological competence, network competence and innovation success. J. Bus. Res. 2004, 57, 548-556. [CrossRef]

116. Fornell, C.; Larcker, D.F. Evaluating structural equation models with unobservable variables and measurement error. J. Mark. Res. 1981, 18, 39-50. [CrossRef]

117. Robinson, J.P.; Shaver, P.R.; Wrightsman, L.S. Measures of Personality and Social Psychological Attitudes: Measures of Social Psychological Attitudes; Academic Press: San Diego, CA, USA, 2013; Volume 1, ISBN 148321984.

118. Baron, R.M.; Kenny, D.A. The moderator-mediator variable distinction in social psychological research: Conceptual, strategic, and statistical considerations. J. Pers. Soc. Psychol. 1986, 51, 1173. [CrossRef]

119. Barczak, G.; Wilemon, D. Team member experiences in new product development: Views from the trenches. RD Manag. 2003, 33, 463-479. [CrossRef]

120. Wang, C.; Hu, Q. Knowledge sharing in supply chain networks: Effects of collaborative innovation activities and capability on innovation performance. Technovation 2017. [CrossRef]

121. Cheng, S.t.; Wu, C.; Lou, H. A self-evolutionary model for automated innovation of construction technologies. Autom. Constr. 2012, 27, 78-88. [CrossRef]

122. Dent, R.J.; Montague, K.N. Benchmarking Knowledge Management Practice in Construction; CIRIA: London, UK, 2004; ISBN 0860176207.

123. Banihashemi, S.; Hosseini, M.R.; Golizadeh, H.; Sankaran, S. Critical success factors (CSFs) for integration of sustainability into construction project management practices in developing countries. Int. J. Proj. Manag. 2017, 35, 1103-1119. [CrossRef]

(C) 2019 by the authors. Licensee MDPI, Basel, Switzerland. This article is an open access article distributed under the terms and conditions of the Creative Commons Attribution (CC BY) license (http://creativecommons.org/licenses/by/4.0/). 